\title{
Prodlužující se soužití s rodiči jako odkládání dospělosti?
}

\section{Prolonging Children's Cohabitation with Parents as Adulthood Postponement?}

\author{
Alena Macková
}

\begin{abstract}
This paper is concerned with research on the prolonging of children's cohabitation with parents. The transformation in patterns of child-parent cohabitation is seen as an indicator of the prolonging of the transition to adulthood. The prolonging of cohabitation with parents is being rethought in the context of broader social changes. On the basis of research on children's leaving of the parental home and transition to adulthood, the article discusses the absence of universal patterns in the leaving of the parental home and its timing, regional differences, and its social and cultural conditionality. These regional specifics shape particular patterns of transition to adulthood and related patterns of leaving the parental home. In general, there are two distinct patterns of leaving the parental home (namely, the early Northern pattern and late Southern pattern) which can help us understand and explain the observed prolonging transitions.
\end{abstract}

KEYWORDS youth, leaving parental home, transition to adulthood

\section{Úvod}

Odstěhování od rodičů je jedním z důležitých kroků dítěte na cestě k dospělosti. Je to moment, v němž je ukončena dlouhá fáze každodenního ovlivňování a zasahování do života dítěte ze strany rodičů. Moment, kdy potomci o svém životě zpravidla začínají rozhodovat sami a nesou takovou zodpovědnost jako nikdy předtím. Především v posledních dvou dekádách lze ale v mnoha evropských zemích sledovat tendenci mladých lidí tyto odchody odkládat do pozdějšího věku. Děti pak mnohdy zůstávají se svými rodiči žít ještě dlouho za hranicí dvaceti let. V současnosti nejsou výjimkou ani třicátníci žijící u rodičů, ačkoliv ti už měli pravděpodobně ve stejném věku své rodiny.

Stat' se zabývá problematikou prodlužování soužití dospělých dětí se svými rodiči. Opuštění domácnosti rodičů je zde zkoumáno v souvislosti se širší oblastí procesů přechodu $\mathrm{k}$ dospělosti, s oblastí procesů, které se v současnosti stávají jedním z důležitých bodů demografického zkoumání. Tato oblast si zaslouží především v poslední době značnou pozornost, protože mezi evropskými zeměmi můžeme vysledovat nejen vzorce načasování odchodu

Sociálni studia. Katedra sociologie FSS MU, 4/2011. S. 13-28. ISSN 1214-813X. 
od rodičů, které je jedním z indikátorů vstupu do dospělosti, ale také dalších, navazujících kroků. S tím, jak narůstá diverzita jiných než tradičních rodinných uspořádání (nárůst institutu kohabitace, singles, trvale bezdětných apod.), se právě odchod od rodičů stává klíčovou událostí definující dospělost. Nemusí to být však samotné odkládání odchodu od rodičů a dlouhé soužití s rodiči, které by se mohlo zdát jako překážka v dalších krocích $\mathrm{k}$ dospělosti, problémem se může stát obzvláště rozvolněnost a nepředvídatelnost jednotlivých kroků, dříve jasně definovaných, ve vyspělých zemích, kde mladí lidé od rodičů odchází nejdřive.

V této přehledové stati se dotkneme problematiky postupného stírání a posouvání hranic mezi dvěma fázemi životního cyklu. V první části si nejprve krátce představíme data z výzkumů odchodů z domácnosti rodičů především v evropských zemích, abychom si ukázali, jak zde vypadají odchody od rodičů, rozlišíme dva modely tranzice, které byly v těchto výzkumech identifikovány, a také makrostrukturální (socioekonomické a kulturní) a mikrostrukturální faktory, které na rozhodnutí jedince, zda v domácnosti rodičů zůstat či zda z ní odejít, působí.

Po uvedení do tématu odchodů od rodičů odchod jako proces zasadíme do kontextu přechodu k dospělosti, zaměříme se na jeho prodlužování a postupné formování nové etapy jako svébytné části životního běhu. Toto období mezi dětstvím a dospělostí zde nebylo vždy, naopak se institucionálně ustanovuje až v posledních desetiletích, kdy k němu sociální vědci přesouvají svou pozornost $\mathrm{v}$ souvislosti s prodlužováním přechodu k dospělosti. Jak můžeme toto období mezi dětstvím a dospělostí konceptuálně uchopit? A které události určují hranici dosažení dospělosti, když, jak upozorňuje Bourdieu (1995: 95), mládí a věk nejsou samozřejmé údaje, ale jsou sociálně konstruované? Na tuto otázku se budeme snažit odpovědět v předposlední podkapitole, abychom ukázali na novost a nesamožrejmost tohoto období, jež se vynořilo díky některým společenským změnám v posledních desetiletích. Které změny to jsou, si představíme v poslední části textu.

\section{Modely tranzice a základní proudy empirického výzkumu}

Od osmdesátých a především devadesátých let 20. století bylo uskutečněno mnoho výzkumů odchodů od rodičů a byla v nich analyzována data z mnoha zemí. Vedle USA, Kanady (např́iklad Card a Lemieux 1997), Austrálie (např́iklad Cobb-Clark 2008) či Japonska (např́klad Raymo 2003) byla velká pozornost výzkumníků soustředěna na evropské státy, především Itálii (např́iklad Aassve, Billari a Ongaro 2000; Becker a kol. 2004; Manacorda a Moretti 2002) a Španělsko (např́ílad Martinéz-Granado a Ruiz-Castillo 2002), kde jsou odchody dětí od rodičů odkládány do pozdějšího věku (viz tabulka 1 , obrázek 1).

Pokud se zaměříme právě na situaci v Evropě, zjistíme, že nejvíce podnětů do problematiky odchodů z domácností rodičů přinesly rozsáhlé komparativní studie, které byly založeny na datech FFS (Fertility and Family Survey) a ECHP (The European Community Household Panel) z let 1994-2001. Novější data, např́iklad z Evropského sociálního výzkumu 2004 (Macková 2009) a 2006 (Chaloupková 2010), trendy načasování podporují a ukazují na ještě další mírný vzestup věku odchodu od rodičů ve srovnání se studiemi z počátku devadesátých let. 
Tabulka 1: Střední věk (medián) odchodu od rodičů (kohorty narozené kolem roku 1960).

\begin{tabular}{|l|c|c|}
\hline & Ženy & Muži \\
\hline Belgie & 21.5 & 23.3 \\
\hline Česká republika & 21.2 & 23.8 \\
\hline Finsko & 19.8 & 21.7 \\
\hline Francie & 19.8 & 21.5 \\
\hline Itálie & 23.6 & 26.7 \\
\hline Litva & 19.8 & 20.3 \\
\hline Lotyšsko & 21.3 & 24.1 \\
\hline Mad'arsko & 21.3 & 24.8 \\
\hline Nizozemsko & 20.5 & 22.5 \\
\hline Norsko & 19.8 & 21.4 \\
\hline Polsko & 22.5 & 25.8 \\
\hline Portugalsko & 21.8 & 24.3 \\
\hline Rakousko & 19.9 & 21.8 \\
\hline Slovinsko & 20.5 & 20.9 \\
\hline Španělsko & 22.9 & 25.7 \\
\hline Švédsko & 18.6 & 20.2 \\
\hline Švýcarsko & 19.2 & 21.5 \\
\hline Velká Británie & 20.3 & 22.4 \\
\hline Východní Německo & 21.2 & 23.8 \\
\hline Západní Německo & 20.8 & 22.4 \\
\hline
\end{tabular}

Fertility and Family Survey (FFS), Kaplan-Meyerova metoda. Zdroj: Billari, Philipov, Baizán 2001: 28.

Obrázek 1: Porovnání věku při odchodu od rodičũ v 18 zemích Evropy.

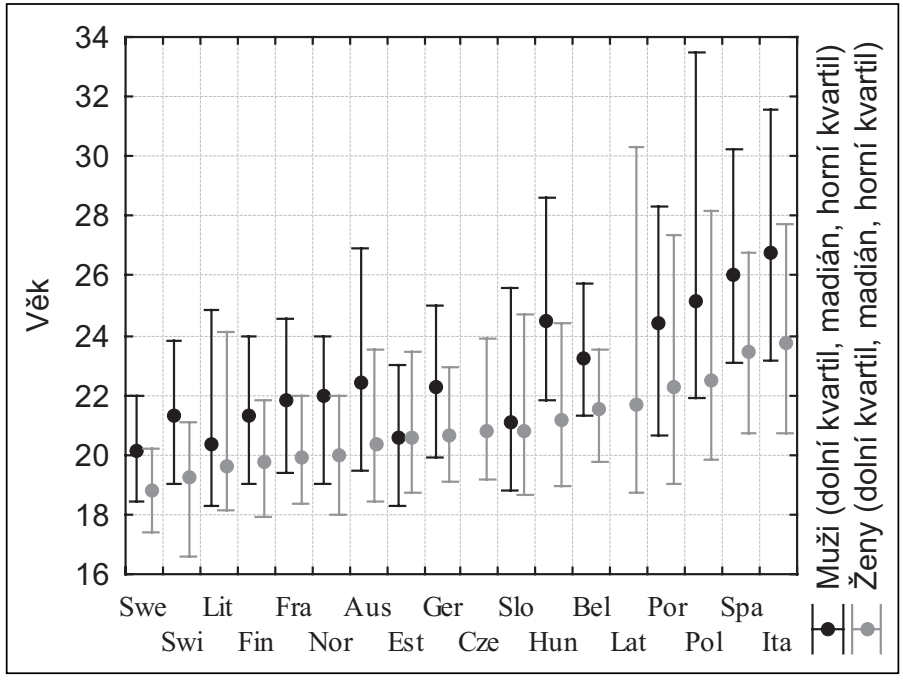

Zobrazeny jsou medián a dolní a horní kvartil odhadnuté pomocí Kaplan-Meierovy metody, rozdělené dle pohlaví, FFS data. Zdroj: Škop 2005: 145. 
Společné pro tyto studie je to, že sledují především načasování tranzice k samostatnému bydlení v různých regionech Evropy. Výsledkem není pouze zjištění, že načasování odchodů je v Evropě velmi heterogenní, ale také to, že v některých regionech Evropy můžeme vysledovat podobné chování a na základě toho identifikovat dva hlavní vzorce tranzice $\mathrm{z}$ domácnosti rodičů. Prvním vzorcem je jižní (nebo středozemský) model, druhým je model severní (někdy také nordický nebo severský) (Aassve, Billari a Ongaro 2000; Aassve a kol. 2005; Billari, Philipov a Baizán 2001 aj.).

Pro jižni model je typické dlouhé období soužití potomků s rodiči. Věk odchodu od rodičủ se v těchto zemích pohybuje blízko pod hranicí třiceti let pro muže a je jen nepatrně nižší pro ženy (zpravidla o dva roky). Jméno modelu je odvozeno z místa jeho výskytu - typickými př́klady jsou Španělsko, Portugalsko a Itálie (tabulka 1), kde je tento fenomén nejviditelnější (z mimoevropských zemí je pak př́kladem Japonsko, kde však model nabývá poněkud jiných charakteristik, viz hikikomori níže). Především italští muži a ženy jsou velmi neochotní opustit domácnost svých rodičů a zapojit se do pracovního procesu a odcházejí od svých rodičů později než mladí lidé kdekoliv jinde (Aassve a kol. 2005). Mezi země s pozdním odchodem můžeme zařadit ještě Lotyšsko a Polsko. Srovnání chování v zemích střední a středovýchodní Evropy je prozatím velmi složité vzhledem k jejich rozdílnému vývoji ve 2. polovině 20. století a vzhledem k tomu, že jim dosud nebyla věnována taková pozornost jako zemím jiným. Pokud se podíváme na rozložení odchodů v těchto zemích (obrázek 1), zjistíme, že ve srovnání s jinými zeměmi zde existuje větší variabilita v čase, kdy $\mathrm{k}$ těmto odchodům dochází. Interkvartilové rozpětí v některých př́padech nabývá hodnoty pěti let i vyšší. Jen velmi pomalu, v rozmezí několika let, tak mladí lidé v těchto zemích opouštějí své rodiče a nemalý podíl z nich s nimi žije i po 30. roce života (tabulka 2). U žen je tento podíl nižší než u mužů.

Druhý model, severní, je charakteristický časnějším opuštěním rodičovských domácností. Severním modelem tranzice se vyznačují země jako Švédsko či Finsko, ale brzký věk odchodu vykazuje také Litva, Slovinsko, Švýcarsko či Francie (tabulka 1). Jako typický př́íklad bývá uváděno Švédsko, kde se u kohorty narozené okolo roku 1960 střední věk odchodu od rodičů pohybuje těsně nad hranicí 20 let a u žen nedosahuje ani 19. Můžeme si také povšimnout, že právě u těchto zemí s časným odchodem rozdíly mezi časem odchodu žen a mužů mnohdy nedosahují ani dvou let, v prrípadě Slovinska tento rozdíl není ani půlroční. Samotné načasování je zde totiž ve srovnání se severním modelem mnohem homogennější. Odchody se zpravidla odehrávají v rozmezí tř́ až čtyř let a pouze malý podíl odchodů je situován do pozdějšího věku. Po 25 . roce života u rodičů zůstává pouze nepatrné procento mladých lidí (tabulka 2).

Studie zabývající se odchody od rodičů v evropských zemích však nezůstaly pouze u identifikace rozdílného chování, ale snažily se nalézt faktory, které se na tomto rozdílném chování podílí, a následně chování a výše zmíněné modely vysvětlit. Protože je proces odchodu od rodičů zprostředkován mnoha demografickými, strukturálními a kontextuálními faktory (pohlaví, rasa, kulturní rozdíly v regionech, zázemí rodičovské domácnosti i např́íklad zdroje samotných dětí), výzkumy se soustředí jak na makrostrukturální, tak na mikrostrukturální proměnné, které na rozhodnutí jedinců působí. 
Tabulka 2: Podíl jedinců ( $\vee \%)$, kteři v daném věku dosud neodešli z domácnosti rodičů (kohorty narozené kolem roku 1960).

\begin{tabular}{|l|c|c|c|c|c|c|c|c|}
\hline & \multicolumn{3}{|c}{ Ženy } & \multicolumn{4}{c|}{ Muži } \\
\hline Věk & $\mathbf{2 0}$ & $\mathbf{2 5}$ & $\mathbf{3 0}$ & $\mathbf{3 5}$ & $\mathbf{2 0}$ & $\mathbf{2 5}$ & $\mathbf{3 0}$ & $\mathbf{3 5}$ \\
\hline Belgie & 70 & 13 & $\mathbf{4}$ & 3 & 87 & 31 & 11 & 8 \\
\hline Česká republika & 67 & 25 & 16 & 15 & 85 & 36 & 18 & 14 \\
\hline Finsko & 45 & 7 & 2 & $<1$ & 68 & 23 & 12 & 11 \\
\hline Francie & 47 & 11 & 5 & 3 & 68 & 20 & 9 & 6 \\
\hline Itálie & 78 & 39 & 20 & 13 & 87 & 61 & 32 & 17 \\
\hline Litva & 49 & 29 & 22 & 21 & 52 & 27 & 20 & 18 \\
\hline Lotyšsko & 59 & 30 & 22 & 20 & 84 & 46 & 33 & 29 \\
\hline Mad'arsko & 63 & 27 & 17 & 15 & 88 & 49 & 27 & 21 \\
\hline Nizozemsko & 57 & 10 & 2 & - & 75 & 25 & 5 & - \\
\hline Norsko & 45 & 7 & $<1$ & $<1$ & 66 & 19 & $<1$ & $<1$ \\
\hline Polsko & 73 & 35 & 23 & 18 & 88 & 55 & 37 & 30 \\
\hline Portugalsko & 63 & 30 & 19 & 15 & 79 & 44 & 26 & 20 \\
\hline Rakousko & 48 & 15 & 6 & 3 & 67 & 30 & 16 & 12 \\
\hline Slovinsko & 54 & 23 & 13 & 10 & 55 & 29 & 15 & 12 \\
\hline Španělsko & 76 & 33 & 14 & 10 & 86 & 54 & 25 & 14 \\
\hline Švédsko & 25 & 2 & 1 & $<1$ & 52 & 7 & 2 & $<1$ \\
\hline Švýcarsko & 38 & 6 & 1 & - & 66 & 20 & 3 & - \\
\hline Velká Británie & 55 & 13 & 5 & - & 73 & 28 & 11 & - \\
\hline Východní Německo & 58 & 13 & 4 & 3 & 72 & 23 & 8 & 5 \\
\hline Západní Německo & 59 & 14 & 4 & 1 & 76 & 30 & 11 & 7 \\
\hline
\end{tabular}

FFS data, Kaplan-Meierova metoda. Zdroj: Billari, Philipov, Baizán 2001: 29

Velká řada vědců zkoumajících vzorce odchodů jim přisuzuje vysokou kulturní i sociální podmíněnost. Jižní model odchodů je do velké míry formován tradicemi a silnými rodinnými vazbami. Mladí lidé zde udržují úzké rodinné vazby a od svých rodičů odcházejí až tehdy, když zakládají rodinu vlastní. Děti zde odcházejí od svých rodičů častěji kvůli bydlení s parterem, než je tomu v modelu severním. Obvykle v těchto oblastech po odstěhování od rodičů nenásleduje fáze studentského samostatného bydlení či bydlení s přáteli před založením vlastní rodiny (Goldscheider a Goldscheider 1998, Holdsworth 2000 aj.). Podobnou situaci lze identifikovat i v katolickém Polsku, v němž je věk založení vlastní domácnosti také vyšší, ačkoliv tak vysoké hodnoty jako v případě Itálie nedosahuje. Ve srovnání s jižními zeměmi, kde je bydlení u rodičů v časných třiceti letech široce akceptovaným chováním, v severských zemích je mnohem více v rozporu s normami (Iacovou 2001). Setrvání u rodičů po delší dobu je - spíše než masovou - individuální záležitostí. V zemích, kde můžeme tento model identifikovat, je u mladých lidí patrnější spíše větší preference nezávislosti a individualismu (Aassve a kol. 2005, Iacovou 2001).

V této souvislosti je často zmiňován koncept tzv. „silné“ a „slabé rodiny“ (Reher 1998). Silný rodinný systém, který je přítomný v jihoevropských (ale také východoevropských) zemích, udržuje déle rodinu pohromadě, protože mezigenerační vztahy jsou zde velmi silné a vyznačují se oboustranností. To znamená, že ponechání dítěte v domácnosti rodičů a jeho podpora ve studiu i na pracovním trhu je poskytována výměnou za jeho společnost 
a př́padnou péči o stárnoucí rodiče. Ve slabém rodinném systému jsou mladí dospělí mnohem více vystaveni riziku chudoby tím, že je zde typická menší závislost na rodičích (a také menší závislost rodičů na dětech). Děti jsou ve „slabé rodině“ mnohem více odkázány na dotace státu.

Vedle této kulturní podmíněnosti se značná část autorů soustředila na roli socioekonomických faktorů na načasování tranzice z domácnosti rodičů. Předpokládali, že svoji roli při rozhodování mohou hrát okolnosti makroekonomického rázu, mezi něž můžeme zařadit například nestabilní trh, vysokou nezaměstnanost a vysokou cenu bytů, které mohou ztěžovat přechod k samostatnému bydlení v určitých evropských regionech. Aassve, Billari, Mazzuco a Ongaro nejprve ve studii Leaving Home Ain't Easy z roku 2001 kombinovali makroekonomické (a institucionální) a mikroekonomické faktory, když analyzovali sílu vlivu mikroekonomických faktorů (zaměstnanosti, př́jimů, př́ijmů domácnosti apod.) na načasování odchodu v závislosti na tom, ve kterém ze čtyř vymezených sociálních systémů se jedinci nacházeli. Výsledky ukázaly obzvláště na to, že v zemích se silnější podporou státu a stabilním trhem (Scandinavia Social Democratic Welfare State) je vliv zkoumaných faktorů zanedbatelný ve srovnání s jižními zeměmi (Southern European Welfare State), efekt ve zbývajících dvou systémech byl smíšený. Později na výzkum navázali Aasve, Davia, Iacovou a Mazzuco (2005) studií zaměřenou na souvislosti mezi chudobou a věkem, v němž mladí opouštějí domácnosti rodičů. Autoři ve studii pracovali s konceptem ,rizika chudoby“, které hrozilo v souvislosti s odchodem od rodičůu, daným věkem i regionem. Podle nich i přes mnohem vyšší riziko velkého snížení životního standardu po odchodu od rodičů v severských zemích jsou to právě mladí v těchto zemích, kteří od rodičů odcházejí nejdříve. Tyto dvě studie naznačují trendy, které mnohé další potvrzují. Tedy to, že spíše než makroekononomické ukazatele ovlivňují jednotlivá rozhodnutí potomků rodinné zdroje a vlastní př́imy. Právě tyto zdroje napomáhají vyrovnat se s př́padným nepř́znivým stavem na trhu bydlení, který se může stát v jihoevropském regionu překážkou k založení vlastní domácnosti (Aassve, Billari a Ongaro 2000; Arnett 1995).

Co se týče mikroekonomických faktorů, už výše jsme se dotkli toho, že jsou regionálně podmíněné. A nejen to, souvislost těchto faktorů s podobou bydlení (s rodiči či samostatně) se mírně liší i mezi pohlavími. Ve zkratce, ekonomická neaktivita či nezaměstnanost mají záporný vliv na proces odchodu od rodičů. Vlastní př́ijmy se ukazují jako signifikantní proměnná - zvyšují pravděpodobnost vlastního bydlení. Ovšem efekt této proměnné není tak silný, jak by se mohlo zdát. Vyšší př́ijmy rodičů bývají naopak asociované s delším soužitím, ale výsledky také nejsou zcela jednoznačné. Argument, který se snaží tuto nejednoznačnost vysvětlit, je ten, že př́ijmy, a to především př́ijmy rodičů, znamenají, že rodiče jsou schopni poskytnout svým dětem větší možnost volby (například studium, cestování apod.), ale nemusí vést k odchodu samotnému. Naopak vysoký př́ijem rodičů/domácnosti může potomka udržovat v domácnosti déle kvůli strachu ze ztráty životního standardu (Ghidoni 2002).

Mezi další individuální faktory demografického charakteru, které byly zkoumány $\mathrm{v}$ souvislosti s prričinami rozdílného načasování odchodu mezi jedinci, byla zejména rodinná struktura. Závěry jsou $v$ tomto př́padě jednoznačnější než u socioekonomických proměnných a nejsou příliš překvapivé. Prvorozené děti, děti z větších rodin, z rozvedených rodin či $\mathrm{z}$ rodin s nevlastním rodičem odcházejí od rodičů dříve. Naopak jedináčci své soužití s rodiči prodlužují (Aquilino 1991, Kiernan 1992, Wister a Burch 1989). 
Na závěr zmíníme ještě poslední významnou oblast výzkumu odchodů z domácnosti rodičů, kterou je asociace odchodů $\mathrm{s}$ dalšími kroky $\mathrm{v}$ tranzici $\mathrm{k}$ dospělosti a která nás přivádí $\mathrm{k}$ dalším podkapitolám, $\mathrm{v}$ nichž se budeme věnovat odchodu $\mathrm{z}$ domácnosti rodičů jako procesu a jako součásti tranzice k dospělosti. Billari, Philipov a Baizán (2001) ve své práci zkoumali spojitosti mezi načasováním a sekvenčností jednotlivých kroků k dospělosti v Evropě. Výsledkem jsou detailní souhrnné statistiky odchodu od rodičů v Evropě a vztah odchodu k jiným procesům přechodu do dospělosti. Ukazují na to, že v jihoevropských zemích jsou tyto kroky mnohem pevněji spjaty a po odchodu z domácnosti rychle následují kroky další (uzavření manželství, plození dětí), než je tomu v zemích severní nebo západní Evropy. Tento trend potvrzují i studie zkoumající vztah k podobě nového bydlení, ${ }^{1}$ které ukazují na to, že v jižních zemích se mladí mnohem pravděpodobněji odstěhovávají kvůli bydlení s partnerem, než je tomu v př́padě jedinců $\mathrm{v}$ jiných zemích, kteří více odcházejí za studiem, bydlet s přáteli či sami (např́íklad Goldscheider a Goldscheider 1998, Holdsworth 2000 aj.).

\section{Odchod jako proces}

Odchod od rodičů je ve většině prŕípadů spíše dlouhodobým procesem než jednorázovou událostí. Prvním důvodem pro toto tvrzení je to, že samotnému odchodu předchází dlouhá fáze zvažování okolností a plánování. Na jedné straně stojí rozhodnutí samotného potomka a na straně druhé mnoho dalších činitelů, které na něj mají vliv. Výše jsme již nastínili některé faktory, které mohou rozhodnutí mladých dospělých formovat. Jsou to tedy faktory dlouhodobé (kulturní a makroekonomické), ale také faktory krátkodobější, individuální, vedoucí bud' k odstěhování se od rodičů, nebo k dalšímu setrvávání. Mezi proměnné, které hrají svou roli v rozhodování, patří rodinné zdroje. Nemáme zde však nyní na mysli zdroje materiální, které jsme zmiňovali výše, ale ty nemateriální, které jsou nepřenosné a k nimž patří např́iklad domácí práce (praní, žehlení, vaření apod.), jež jsou potomkovi doma poskytovány (Hartley 1993: 38). Kromě strachu ze snížení životního standardu i pohodlí může odchod pro potomky přinášet i obavu ze ztráty úzkého vztahu k rodičům, jimi poskytovaného zázemí, emocionální podpory a jistoty. Na straně druhé může zrrízení vlastní domácnosti znamenat pro mladého člověka mnohem větší míru svobody a odpovědnosti za sebe sama. Mezigenerační soužití s sebou přináší nejen nedostatek autonomie v mnoha oblastech, ale také nižší míru soukromí. Na miskách vah se tak ocitá mnoho protichůdných zájmů dále formovaných vnějšími vlivy, které ovlivňují jedincovu volbu, zda odejít, či s rodiči nadále zůstávat. Krátce řečeno, touha po sebenaplnění, individualizaci a osamostatnění se je konfrontována s některými, a nejen vnějšími omezeními (Hartley 1993).

Druhým důležitým důvodem pro chápání odchodu od rodičů jako dlouhodobějšího procesu je skutečnost, že odchod může být pouze dočasnou záležitostí. Mladí se mohou vracet domů po ukončení partnerského či manželského svazku, po ztrátě zaměstnání nebo například v tíživé finanční situaci. Návraty po delším období samostatného bydlení mohou být pro obě strany, jak pro děti, tak pro rodiče, těžší než soužití před odchodem. Těžší z toho důvodu, že si během odloučení mohli vypěstovat jiné návyky a osvojit rozdílné způsoby života. Navíc

Např́iklad zda se jedná o studentské ubytování, bydlení s přáteli či samostatný byt. 
po období autonomie se mladí opět ocitají pod dohledem rodičů a opět ztrácejí soukromí. $\mathrm{K}$ těmto návratům $\mathrm{k}$ rodičům tendují především ti, kteří od rodičů odešli $\mathrm{v}$ časném věku. Zatímco podíl Italů a Italek, kteří by se vraceli k rodičům, je mizivý, mladí v severoevropských a západních zemích se domů v mnoha př́ípadech vracejí i několikrát (Mitchell 2007).

To, že se odchod proměňuje $\mathrm{v}$ delší proces, nás přivádí i $\mathrm{k}$ jistým konceptuálním problémům. Jak upozorňuje Škop (2005), zatímco datum narození prvního dítěte nebo sňatku mohou být určeny zcela přesně, odchod od rodičů nemusí být tak jednoznačný. V některých případech se může jednat o odchod postupný. V takovém př́padě žije mladý člověk odděleně od svých rodičů, ale může na nich být stále finančně závislý. Typickým prríkladem jsou studenti. S rozmachem možností studia a stále větší nutností dosažení vysokoškolského vzdělání (Beck 2004) mladí nyní často studují ještě dlouho po dosažení dvacátého roku života a nejsou ekonomicky soběstační. Prodlužují tak období svého soužití s rodiči alespoň po dobu, dokud nejsou schopni se sami uspokojivě ekonomicky zajistit (Aassve a kol. 2005), anebo se po dokončení studia k rodičům vrací. Právě návrat k rodičům se ukazuje jako konceptuální problém, který se ale dá řešit například sledováním prvního odchodu. U postupného odchodu je podle Škopa (2005) možné se zaměřit na další indikátory, které mohou poskytnout detailnější náhled - například otázku finanční výpomoci, otázku praní oblečení atd.

\section{Odchod od rodičů jako součást tranzice $k$ dospělosti}

Tranzice k dospělosti je v sociologii definována jako delší proces sestávající ze série dílčích přechodů. Ačkoliv odstěhování od rodičů bývá často považováno za jeden z nich, v definování všech konkrétních a klíčových kroků tohoto procesu nepanuje zcela shoda. Billari (2001) např́iklad mezi ně řadí konec každodenního vzdělávání, první zaměstnání, odchod od rodičů, soužití s partnerem a narození prvního dítěte. Corijn pak jeho výčet dopln̆uje o další tři procesy - první sexuální styk, první partnerství a první sňatek (Škop 2005).

Iacovou a Berthoud (2001) rozdělují proces přechodu na dvě základní oblasti. Ta první v sobě zahrnuje přechod z každodenního vzdělávání do zaměstnání, druhá oblast právě odchod od rodičů a založení vlastní rodiny. Jejich definici se přibližuje i Chaloupková (2010), která tyto dvě fáze definuje jako přesun od ekonomické závislosti na rodičích k nezávislosti a přesun od orientační rodiny k prokreační. Ovšem Furstenberg, McCloyd, Rumbaut a Settersten (2003) na základě výzkumu dokládají, že manželství a i narození dítěte postupně ztrácí pro definování dospělosti na významu. Rozhodujícími se v současnosti zdají být procesy získání finanční nezávislosti (přechod k zaměstnání) a právě odchod od rodičů. Tato proměna se zdá být proměnnou logickou vzhledem k tomu, že mladí nyní často tendují k jiným než tradičním rodinným uspořádáním.

Iacovou (2001) považuje zejména odstěhování od rodičů za rozhodující (a většinou také za první) moment přechodu od dětství $\mathrm{k}$ dospělosti. Je jedním z klíčových zlomů a událostí vymezujících pojem dospělosti, ruku v ruce s finančním osamostatněním, zakončením vzdělávání a započetím práce na plný úvazek (Billari a Liefbroer 2007). Odstěhování je klíčovým krokem, nebot' vyžaduje od dítěte v kontextu tranzice k dospělosti značnou míru nezávislosti. Přináší s sebou jak autonomii v oblasti bydlení, tak většinou i autonomii finanční. Podle Arnetta (2004) je to pro mladé lidi především finanční nezávislost na rodičích (často úzce 
spojená se samostatným bydlením), která se stává důležitým mezníkem ve vnímání sebe sama jako dospělého. Zatímco uzavření manželství bylo důležité jen asi pro 15 \% dotazovaných mladých lidí, více než polovina z nich považovala za důležitý milník odchod od rodičů.

Období přechodu $\mathrm{k}$ dospělosti se tak stává mnohem nejasnějším a mnohem hůřre definovatelným, než tomu bylo dříve. Iacovou a Berthoud (2001) na datech z evropských zemí, $\mathrm{v}$ nichž zkoumali jednotlivé fáze přechodu $\mathrm{k}$ dospělosti a jejich spjatost a načasování, dokazují, že ještě před několika desetiletími byly tento přechod a jeho jednotlivé fáze jasně vymezeny a jednotlivé kroky měly přesný a také rychlý sled. V některých regionech je tomu však už jinak. Hovoříme tady obzvláště o zemích severních (ale také jiných západních), v nichž se tranzice $\mathrm{k}$ dospělosti stává dlouhou a nepředvídatelnou etapou životního běhu. Proces odchodu od rodičů, život s partnerem, uzavření manželství a narození dítěte spolu již dále nejsou spjaté, jak je tomu např́klad v zemích jihoevropských. ${ }^{2}$ Pro stále větší počet mladých lidí ve vyspělých zemích se tak toto přechodné období stává delším a delším, a zároveň se podoby těchto přechodů spolu s rychlými společenskými změnami zdají stále hůře definované a hranice mezi nimi zamlžené více, než tomu bylo dříve.

Ideu odkládání tranzice zmínil Kohler ve spojení s popisem odkládání prvních porodů, ale je aplikovatelná i na jiné události během přechodu k dospělosti. Côté (2000) zmiňuje tzv. bumerangový efekt. ${ }^{3}$ Podle něj se sice mladí lidé dříve či později odstěhují od rodičů, ale také se zase vracejí zpátky, vstupují do zaměstnání a později se vracejí opět ke studiu apod. Côté zmiňuje skutečnost, že se toto období tak může pro některé stát dokonce pastí, v níž se proces přechodu k dospělosti zastaví. V odborné literatuře objevují termíny jako „odložená generace“ (generation on hold) či „uvězněná dospělost“ (arrested adulthood). Ve Velké Británii používají termínu ,postadolescence“ (post-adolescence), v Nizozemsku se hovoří o „přestárlých mladých dospělých“ (over-aged young adults) a v Kanadě a Austrálii je přechodná perioda mezi dětstvím a dospělostí definována jako „rozšířená tranzice“ (extended transition) (Wyn 2004: 6).

\section{Konceptualizace nového období}

S tím, jak se přechodové fáze postupně přesouvají do vyššího věku, stírají se dříve jasné hranice mezi dětstvím a dospělostí. „Mládi““ je relativně novým fenoménem, podle Iacovou a Berthouda (2001) byla ještě asi před čtyřiceti nebo padesáti lety životní stádia pevněji ohraničena a vymezena. V současnosti se mnozí snaží toto nové období životního běhu, které předchází dosažení dospělosti, konceptuálně uchopit s ohledem na institucionální a sociální kontext, v němž se toto období objevuje, a s ohledem na jednání jedince.

2 Cavalli a Galland rozlišují tři široké, na geografické poloze založené vzorce tranzice $\mathrm{k}$ dospělosti v současných západoevropských zemích. Podle středozemského vzorce mladí lidé zůstávají dlouho u rodičů a odchod je synchronizován s manželstvím. Ve francouzském a severoevropském předchází utváření rodiny založení domácnosti a čas, kdy žije člověk sám, se prodlužuje. A podle posledního, britského vzoru mladí lidé sice velmi brzy odcházejí do zaměstnání a jsou ekonomicky soběstační, ale odkládají jak založení vlastní domácnosti, tak rodiny (Billari, Philipov a Baizán 2001).

3 Barbara A. Mitchell (2007: 8) hovoří o „boomerang age“. Tento termín zjednodušeně charakterizuje současné sociokulturní prostředí v industrializovaných zemích, v němž se mladí vyvíjejí a dospívají. 
Nejčastěji užívanými termíny pro mladé lidi mezi obdobím dětství a dospělostí je termín mládí a adolescence. Termín adolescence byl poprvé použit už na počátku 20. století B. S. Hallem k popisu především psychologických procesů spojených s nástupem puberty, k popisu období psychického, emociálního a sexuálního vývoje probíhajícího především mezi 12. a 18. rokem života. Ve srovnání s ním je termín mládí sociology užíván poněkud volněji. Mládí pokrývá mnohem větší časový úsek než adolescence a zahrnuje i jedince s velmi odlišnými zkušenostmi (Wallace a Kovatcheva 1998). Furlong a Cartmel (2007) jej definuje jako etapu částečné závislosti (semi-dependency) formovanou legislativou i kulturními normami. Etapu, která vytvárí most mezi absolutní závislostí v dětství a nezávislostí v dospělosti. Právě kvůli širřce trendů bývá pojmu mládí vytýkána jeho vágnost a jsou hledány jiné koncepty pro popis nové životní etapy.

V tomto kontextu je často zmiňován koncept „,vynořující se dospělosti“ (emerging adulthood) J. J. Arnetta (2004), který toto období naopak vnímá jako samostatnou vývojovou etapu. Ta vzniká díky tomu, že se jednotlivé sociálně vymezené kroky přechodu k dospělosti odkládají do vyššího věku. „Vynořující se dospělost“ je přechodovou fází typickou (stejně jako např́klad ,prodloužená adolescence“ Erika H. Eriksona ${ }^{4}$ ) pro vyspělé společnosti. Mladí mezi 18. a 25. rokem se již necítí dětmi, zároveň se ale ještě nepovažují za dospělé. Arnett formuluje pět základních charakteristických rysů fáze „vynořující se dospělosti“, jsou to: 1) prozkoumávání vlastní identity; 2) nestabilita; 3) zaměřenost na sebe sama; 4) nevnímání sebe sama ani jako dítěte, ani jako dospělého; a 5) možnosti, které se v tomto období před jedincem objevují. „Vynořující se dospělost“ je stadiem sebepoznávávání, objevování svých schopností, možností a zájmů. Jedinci v tomto období již nejsou na svých rodičích závislí tolik jako v období adolescence, přesto ale stále ještě nejsou samostatní a nejsou spoutáni povinnostmi a závazky. Pro překonání fáze „vynořující se dospělosti“ je zapotřebí přijetí zodpovědnosti za sebe sama, dosažení nezávislosti ve svém rozhodování a také finanční autonomie. Kromě termínu „vynořující se dospělost“ se můžeme ještě setkat s termínem ,post-adolescence“, který na počátku 90. let použil O. Galland (Furlong a Cartmel 2007), „mladá dospělost“" (EGRIS 2001) nebo „psychologická dospělost“ (Côté 2000).

V odborné literatuře i ve veřejném diskurzu můžeme narazit na další méně užívané termíny, které nabývají významu většinou v regionálních kontextech a na základě svých lokálních charakteristik. Pojmy spojované př́mo s problematikou dětí závislých na svých rodičích a žijících v jejich domácnosti jsou např́klad parasite singles, co-residing adults, mama boys, twixters, úžeji např́íklad hikikomori, NEET či freeters. Termín parasite singles, podobně jako co-residing adults, je definován jako nesezdaní muži a ženy mezi 20 a 34 lety, kteří žijí se svými rodiči nebo rodičem, bez ohledu na to, zda studují či pracují (Takami a Watanabe 2003: 6). Mama boys se svým negativním nádechem velmi podobají termínu parasite singles. Jedná se však konkrétně o označení pro italské muže, třicátníky, kteří žijí u svých rodičů a využívají péče svých matek. Tzv. twixters Yelowitz (2006: 2) popisuje jako mladé dospělé, již se ve svých dvaceti odmítají usadit, zavázat se a kteří žijí mladistvým životním stylem,

4 Hlavním pojmem objevujícím se v Eriksonově (1999) psychologickém konceptu „mladé dospělosti“ je identita. V souvislosti s rozvinutými industriálními zeměmi Erikson hovoří o ,prodloužené adolescenci“" (prolonged adolescence). 
zatímco stále bydlí u rodičů. Hikikomori je fenomén specifický pro Japonsko. ${ }^{5}$ Jedná se o mladé izolované od společnosti, dobrovolně se uzavírající ve svých pokojích a odmítající sociální kontakty. Vznik této početné skupiny lidí je v Japonsku vysvětlován nebývalým tlakem na mladé jedince a velkými očekáváními a nároky společnosti. Uzavírání se před touto společností je potom způsob, jakým se mladí Japonci a Japonky snaží tomuto tlaku uniknout. Dospělé děti se tak v těchto extrémních prŕpadech stávají zcela nesamostatnými a závislými na svých rodičích (Furlong 2008).

\section{Širší sociální kontext}

Jak jsme si výše ukázali, v posledních desetiletích se vstup do dospělosti prodloužil a především v západních zemích se rovněž oddálily jeho jednotlivé kroky a jejich variabilita v načasování je velká. Na základě zjištěných rozdílů a identifikovaných typů chování, nejen co se týče přechodu k vlastnímu bydlení, ale celkové rozdílné tranzice k dospělosti, se nyní budeme snažit podívat na jednotlivé vzorce a vysvětlit jejich vznik a povahu na pozadí hlubších společenských změn.

Už od druhé poloviny 60. let do let osmdesátých jsme se v zemích západní Evropy mohli setkat s výraznými změnami demografického chování, které popisuje teorie druhé demografické tranzice (van de Kaa 1987). Po poválečném baby-boomu, kdy došlo nejen ke snížení věku odchodu od rodičů, ale také věku, kdy mladí vstupovali do manželství a zakládali rodiny, dochází v horizontu asi dvaceti let $\mathrm{k}$ výrazné proměně rodinného chování. $\mathrm{V}$ tomto období tak dochází například k poklesu úhrnné plodnosti, snížení počtu dětí, snížení průměrného věku sňatku, vzestupu rozvodovosti a praxe nesezdaného soužití, vnímání kohabitace jako alternativy manželství či vzestupu dobrovolné bezdětnosti. Celkově je proces druhé demografické tranzice spjat s posunem směrem k individualismu v demografickém chování, což vede k tomu, že se životní běh stává mnohem flexibilnějším a zkušenosti jednotlivců jsou mnohem heterogennější. Konkrétním výsledkem procesu individualizace životního běhu je nové chování mladých lidí i v oblasti variability bydlení - např́íklad kohabitace, studentské bydlení, single bydlení apod. -, které může znesnadňovat i jasné definování jednotlivých kroků k dospělosti.

Tento proces se však týká pouze zemí západní Evropy. Vysvětlení nás odkazují k tomu, že se jedná o demokracie, které jsou kapitalisticky a tržně orientované. Ty země, v nichž byla nukleární rodina jednou z podmínek existence systému (Beck 2004). S příchodem modernizace však dochází ke zpochybnění mnoha dosud fungujících principů a sama modernizace vytvořila prostor pro nové modely chování, nástup druhé demografické revoluce a procesu individualizace. Pak ty společnosti, kde je proces individualizace mladých dospělých, a obecněji i proces druhé demografické tranzice, na vysokém stupni (např́iklad Švédsko), vykazují vyšší homogenitu v chování ohledně odchodů od rodičů. Nicméně, jak už jsme se dozvěděli, další tranzice jsou povahy velmi heterogenní ve srovnání se zeměmi jižní Evropy a některými zeměmi Evropy střední a východní. Celková tranzice k dospělosti se pak zdá být výsledkem pokračujícího procesu individualizace životního běhu. Respektive homogenní

Počet takto označovaných lidí je v Japonsku odhadován na jeden milion. 
povaha tranzice $\mathrm{z}$ domácnosti a heterogenní povaha dalších tranzic $\mathrm{k}$ dospělosti naznačuje, že spíše než aby se odchod zdál být důsledkem individualizované volby jako takové, ${ }^{6}$ protože dlouhé soužití s rodiči podle severního vzorce je zde proti sociálním normám a mladí lidé tak nemají ve svém odchodu tolik prostoru pro volbu, se odchod z domácnosti rodičů jeví jako podmínka pro to, aby člověk mohl další individualizované volby činit (Billari, Philipov a Baizán 2001).

Argument o individualizaci životních drah nás vrací zpět k Reherově (1998) pojetí „silné a slabé rodiny“, protože právě tyto dva modely následně vedou k přijetí dalších rolí a vzorců chování mladými lidmi. Nastíněné výzkumy sledující spjatost a načasování jednotlivých kroků $\mathrm{k}$ dospělosti v národních kontextech naznačují, že model „slabé rodiny“ přítomný právě $\mathrm{v}$ západních zemích a spojený $\mathrm{s}$ brzkým nezávislým bydlením, je asociován s odkládáním manželství a přijetím méně tradičních hodnot, než jaké sledujeme u těch jedinců, již zůstávají u rodičů. Naopak model ,silné rodiny“ přítomný v jižních zemích vede $\mathrm{k}$ prrijetí tradičních hodnot, a proto je i odchod od rodičů pravděpodobněji asociován $\mathrm{s}$ uzavíráním manželství a zakládáním rodiny. Argumentaci ve své podstatě podporuje i Arnett (1995), který rozlišuje dva typy socializace, ,širokou“ (broad) a „úzkou“ (narrow), přičemž vysoká hodnota individualizace je připisována socializaci široké, charakteristické pro západní země. Vyznačuje se nezávislostí a časnějším rozvojem, zatímco ve společnostech se socializací úzkou je naopak od raných let vštěpován smysl pro zodpovědnost, vzájemnou závislost a výchova také důsledně odrazuje od odchylek z kulturních norem. ${ }^{7}$

Co se týče zemí východní a střední Evropy, ukazuje se, že se některé přiklánějí k jižnímu a jiné k severnímu modelu, ${ }^{8}$ ale větší pozornost ve spojení s tranzicí těmto zemím nebyla dosud věnována. Rozmanitost načasování tranzic zde poukazuje na různé vývoje zemí po pádu ,železné opony“ či na pozdní nástup druhé demokratické tranzice v některých z nich. A právě proto tato oblast může být výzvou pro další komparativní studie, které by mohly tyto procesy osvětlit.

$6 \quad$ Na úlohu individualizace právě u tranzice $\mathrm{k}$ dospělosti a odchodu od rodičů upozorňuje A. Giddens (1986), podle nějž se opuštění domova jeví jako většinou promyšlená volba, ačkoliv je formována faktory, jež jedinec sám nevnímá.

7 Takto definované dva typy socializace následně Arnett aplikoval na samotný přechod k dospělosti a načasování jeho dílčích tranzic. Ve společnostech se socializací ,širokou“ existuje větší rozmanitost $\mathrm{v}$ čase, kdy jedinci vstupují do těchto přechodů, a mladí lidé jednají především v závislosti na vlastních preferencích. Ve společnostech se socializací „úzkou“ je načasování závislé spiše na specifických kulturních normách ovlivňujících tranzice a společenských podmínkách vůbec. Jedinci se tak spíše než podle vlastních preferencí rozhodují ve vleku společenských očekávání a okolností (Arnett 1995).

8 Výjimečně se např́klad objevily snahy o vysvětlení těchto rozdílů v tranzicích na teorii tzv. Hajnalovy linie. Tato vysvětlení se však ukázala jako nedostačující a př́liš zjednodušující (Billari, Philipov a Baizán 2001). 


\section{Závěr}

V současnosti jsme se stali svědky situace, v níž se mnoho vyspělých zemí potýká s poklesem sňatečnosti a porodnosti či s odkládáním plození dětí do vyššího věku. Cílem této přehledové práce bylo podívat se na tento fenomén $\mathrm{z}$ širšího pohledu tranzice $\mathrm{k}$ dospělosti. Skrze jednu z prvních tranzic $\mathrm{k}$ dospělosti - odchod z domácnosti rodičů a jeho načasování a charakteristiky - jsme mohli identifikovat dva širší vzorce chování při přechodu k dospělosti: vzorec časnějšího odchodu, jímž se vyznačují země severní Evropy a jenž bývá asociován s heterogenní povahou dalších tranzic a jejich rozvolňováním, a odchodu pozdního, jenž je typický pro jihoevropské země a v němž je odchod celkem pevně spjat s dalšími kroky $\mathrm{k}$ dosažení dospělosti (uzavření manželství, početí).

Nové koncepty jako „vynořující se dospělost“, „,mladá dospělost, „mládi““ i další jsou založené na předpokladu, že člověk nově prochází obdobím, které spočívá v oddalování dosažení dospělosti. Nejen tranzice z domácnosti rodičů (tedy tranzice k ekonomické nezávislosti na rodičích), ale celá tranzice k dospělosti se nyní stává dlouhým a nepředvídatelným procesem. Tento trend můžeme identifikovat především v zemích severní a západní Evropy, které následují severský vzorec. Ve světle výzkumů se však zdá, že to není dlouhé soužití s rodiči, které by vedlo k výraznému odkládání dospělosti a zakládání rodiny, protože s novými vzorci chování - singles či bezdětní - se setkáváme právě v prŕípadě zemí, kde je tranzice z domácnosti rodičů nejčasnější. Právě $v$ těchto zemích se rodinná tranzice pro mnohé stává méně důležitou, a je tak odkládána do vyššího věku nebo není absolvována vůbec. Ovšem jak výzkumy naznačují, nejsou to ani tak nové socioekonomické podmínky, které by mezi evropskými regiony způsobovaly tyto rozdíly v podobě tranzice, ale můžeme, především s ohledem na identifikované modely, spíše hovořit o sociokulturní podmíněnosti v daných oblastech, o síle tradice na straně jedné a o individualizaci životních stylů na straně druhé.

\section{Literatura}

AASVE, Arnstein; BILLARI, Francesco C.; MAZZUCO, Stefano; ONGARO, Fausta. Leaving Home Ain't Easy A Comparative Longitudinal Analysis of ECHP Data [online]. MPIDR Working Paper 2001-038, Rostock: Max Planck Institute for Demographic Research, 2001, [cit. 11. 1. 2012]. Dostupné na www: <http://demogr.mpg.de/Papers/Working/wp-2001-038.pdf >

AASVE, Arnstein; DAVIA, Maria A.; IACOVOU, Maria; MAZZUCO, Stefano. Does Leaving Home Make You Poor? Evidence from 13 European Countries [online]. ISER Working Paper 24, Essex: Institute for Social and Economic Research, 2005, [cit. 11. 1. 2012]. Dostupné na www: <http://iser. essex.ac.uk/publications/working-papers/iser/2005-24.pdf>

AQUILINO, William S. Family Structure and Home-Leaving: A Further Specification of the Relationship. Journal of Marriage and the Family, 1991, roč. 53, č. 4, s. 999-1010. ISSN 0022-2445.

ARNETT, Jefferey Jensen. Emerging Adulthood: The Winding Road from the Late Teens Throught the Twenties. Oxford: Oxford University Press, 2004, 280 s. ISBN 0195173147.

ARNETT, Jeffrey Jensen. Broad and Narrow Socialization: The Family in the Context of a Cultural Theory. Journal of Marriage and the Family, 1995, roč. 57, č. 3, s. 617-628. ISSN 0022-2445.

ARNSTEIN, Aassve; BILLARI, Francesco C.; ONGARO, Fausta. The Impact of Income and Employment Status on Leaving Home: Evidence from the Italian ECHP Sample [online]. MPIDR Working 
Paper 2000-012, Rostock: Max Planck Institute for Demographic Research, 2000, [cit. 11. 1. 2012]. Dostupné na www: <http://demogr.mpg.de/Papers/Working/wp-2000-012.pdf>

BAUMAN, Zygmunt. Individualizovaná společnost. Praha: Mladá Fronta, 2004, 290 s. ISBN 80-204-1195-X.

BECK, Ulrich. Riziková společnost. Praha: Sociologické nakladatelství, 2004, 431 s. ISBN 8086429326.

BECKER, Sascha O.; BENTOLILA, Samuel; FERNANDES, Ana; ICHINO, Andrea. Job Insecurity and Children's Emancipation: The Italian Puzzle [online]. Working Paper 2004-04, Madrid: CEMFI (The Center for Monetary and Financial Studies), 2004, [cit. 11. 1. 2012]. Dostupné na www: <ftp://ftp.cemfi.es/wp/04/0404.pdf>

BILLARI, Francesco C. Becoming an Adult in Europe: A Macro(/Micro)-Demographic Perspective. Demographic Research - Special Collection [online]. 2004, roč. 3, č. 2, [cit. 15. 10. 2011]. Dostupné na www: <http://demographic-research.org/special/3/2/S3-2.pdf >

BILLARI, Francesco C.; LIEFRBROER, Aartt C. Should I Stay or Should I Go? The Impact of Age Norms on Leaving Home. Demography, 2007, roč. 44, č. 1, s. 181-198. ISSN 0070-3370.

BILLARI, Francesco C.; PHILIPOV, Dimiter; BAIZÁN, Pau. Leaving Home in Europe: the Experience of Cohorts Born around 1960 [online]. MPIDR Working Paper 2001-014. Rostock: Max Planck Institute for Demographic Research, 2001, [cit. 11. 1. 2012]. Dostupné na www: <http://demogr. mpg.de/papers/working/wp-2001-014.pdf>

BOURDIEU, Pierre. Sociology in Question. London: SAGE Publications, 1995, 184 s. ISBN 0803983379.

CARD, David; LEMIEUX, Thomas. Adapting to Circumstances: The Evolution of Work, School and Living Arrangements Among North American Youth [online]. Working Paper 386, Princeton: Princeton University, 1997, s. 172-213, [cit. 11. 1. 2012]. Dostupné na www: <http:// nber.org/ chapters/c6805.pdf $>$

COBB-CLARK, Deborah A. Leaving Home: What Economics Has to Say about the Living Arrangements of Young Australians. Australian Economic Review, 2008, roč. 41, č. 2, s. 160-176. ISSN 0004-9018.

CÔTÉ, James E. Arrested Adulthood: The Changing Nature of Maturity and Identity. New York: New York University Press, 2000, 245 s. ISBN 0814715982.

ERIKSON, Erik H. Životní cyklus rozšiřený a dokončený. Doplněné vydání. Praha: Nakladatelství Lidové noviny, 1999, $128 \mathrm{~s}$. ISBN 807106291X.

European Group for Integrated Social Research (EGRIS). Misleading Trajectories: Transition Dilemmas of Young Adults in Europe, Journal of Youth Studies, 2001, roč. 4, č. 1, s. 101-118.

FURLONG, Andy. The Japanese Hikikomori Phenomenon: Acute Social Withdrawal among Young People. Sociological Review, 2008, roč. 56, č. 2, s. 309-325. ISSN 0038-0261.

FURLONG, Andy; CARTMEL, Fred. Young People and Social Change. New York: Open University Press, 2007, 185 s. ISBN 0335218687.

FURSTENBERG, Frank F.; KENNEDY, Sheela; MCLOYD, Vonie C.; RUMBAUT, Rubén G.; SETTERSTEN, Richard A. Between Adolescence and Adulthood: Expectation about the Timing of Adulthood [online]. Research Network Working Paper No. 1, The Network on Transitions to Adulthood, 2003, [cit. 11. 1. 2012]. Dostupné na www: <http://transad.pop.upenn.edu/downloads/ between.pdfs

GIDDENS, Anthony. The Constitution of Society. Cambridge: Polity Press, 1986, 402 s. ISBN 0745600077.

GOLDSCHEIDER, Frances K.; GOLDSCHEIDER, Calvin. Family Structure and Conflict; Nest-leaving Expectations of Young Adults and Their Parents [online]. Journal of Marriage and the Family, 1989, roč. 51, č. 1, s. 87-97, [cit. 11. 1. 2012]. Dostupné na www: <http://jstor.org/stable/352371> 
GOLDSCHEIDER, Frances K.; GOLDSCHEIDER, Calvin. The Effects of Childhood Family Structure on Leaving and Returning Home. Journal of Marriage and the Family, 1998, roč. 60, č. 3, s. 745-756. ISSN 0022-2445.

HARTLEY, Robyn. Young Adults Living at Home [online]. Family Matters, 1993, č. 36, s. 35-37, [cit. 11. 1. 2012]. Dostupné na www: <http://aifs.gov.au/institute/pubs/fm1/fm36rh1.html >

HOLDSWORTH, Clare. Leaving Home in Britain and Spain. European Sociogical Review, 2000, roč. 16, č. 2, s. 201-222. ISSN 0266-7215.

CHALOUPKOVÁ, Jana (ed.). Proměny rodinných a profesnich startü. Praha: Sociologický ústav AV ČR, 2010, 167 s. ISBN 9788073301859.

IACOVOU, Maria. Leaving Home in the European Union [online]. Working Papers of the Institute for Social and Economic Research 2001-18, Colchester: University of Essex, 2001, [cit. 11. 1. 2012]. Dostupné na www: <http://iser.essex.ac.uk/files/iser_working_papers/2001-18.pdf>

IACOVOU, Maria; BERTHOUD, Richard. Young People's Lives: A Map of Europe. Institute for Social and Economic Research. Colchester: University of Essex. 2001, 64 s. ISBN 185871205X.

KIERNAN, Kathleen E. The Impact of Family Disruption in Childhood on Transition Made in Young Adult Life. Population Studies, 1992, roč. 46, č. 2, s. 213-234. ISSN: 00324728.

KOHLER, Hans-Peter; BILLARI, Franceso C.; ORTEGA, José Antonio. The Emergence of Lowest-low Fertility in Europe during the 1990s. Population and Development Review, 2002, roč. 28, č. 4, s. 641-680. ISSN 0098-7921.

MACKOVÁ, Alena. Opouštěni domácností rodičů v ČR a vybraných evropských zemích: Sekundární analýza dat „European Social Survey 2004“. Bakalářská práce, Brno: Fakulta sociálních studií MU, 2009, $47 \mathrm{~s}$.

MANACORDA, Marco; MORETTI, Enrico. Intragenerational Transfers and Household Structure - Why Do Most Italian Youths Live With Their Parents? Journal of the European Economic Association, 2002, roč. 4, č. 4, s. 800-829. ISSN 1542-4766.

MARTINÉZ-GRANADO, Miate; RUIZ-CASTILLO, Javier. The Decisions of Spanish Youth: A Cross-Section Study. Journal of Population Economics, 2002, roč. 15, č. 2, s. 305-330, ISSN 0933-1433.

MITCHELL, Barbara A. The Boomerang Age: Transitions to Adulthood in Families. London: Transactions Publisher, 2007, 230 s. ISBN 978-0-202-30978-1.

RAYMO, James M. Premarital Living Arrangements and the Transition to First Marriage in Japan. Journal of Marriage and Family, 2003, roč. 65, č. 2, s. 302-315. ISSN 0022-2445.

REHER, David S. Family Ties in Western Europe: Persistent Contrasts [online]. Population nad Development Review, 1998, roč. 24, č. 2, s. 203-234, [cit. 11. 1. 2012]. Dostupné na www: <http:// geps.es/fileadmin/docs/biblioteca/032_Reher_Family_in_Europe_PDR.pdf >. ISSN 17284457.

ŠKOP, Michal. Statistická analýzy přě̌iváni s aplikaci na proces odchodu od rodiču v České republice. Disertační práce, Praha: Přírodovědecká fakulta UK, 2005, 229 s.

TAKAMI, Akira; WATANABE, Koji. More 'Parasite Singles', Fewer Children, and More Senior Citizens in Japan [online]. Př́spěvek přednesený na konferenci 21st Population Census Conference. Kyoto, 19.-21. 2003, 2003, [cit. 11. 1. 2012]. Dostupné na www: <http://ancsdaap.org/cencon2003/Papers/ Japan/Japan.Takami\%20and\%20Watanabe.pdf $>$

VAN DE KAA, Dirk. Europe's Second Demoraphic Transition, Population Bulletin, 1987, roč. 42, č. 1, s. 1-59. ISSN 0032468X.

WALLACE, Claire; KOVATCHEVA, Sijka. Youth in Society: The Construction and Deconstruction of Youth in East and West Europe. London: Macmillan Press LTD, 1998, 243 s. ISBN 0333652258.

WISTER, Andrew V.; BURCH, Thomas K. The Family Environment and Leaving the Parental Home [online]. Journal of Marriage and the Family, 1989, roč. 51, č. 3, s. 605-613, [cit. 11. 1. 2012]. Dostupné na www: <http://jstor.org/stable/352160>. ISSN 17413737. 
WYN, Johanna. Becoming Adult in the 2000s: New Transitions and New Careers [online]. Family Matters 2004, č. 68, s. 6-12, [cit. 11. 1. 2012]. Dostupné na www: $<$ http://aifs.gov.au/institute/pubs/ fm2004/fm68/jw.pdf>

YELOWITZ, Aaron. 2006. Young Adults Leaving the Nest: The Role of Cost-of-Living [online]. Research Network on Transitions to Adulthood Working Paper, [cit. 14. 10. 2011]. Dostupné na www: <http:// transad.pop.upenn.edu/downloads/Yelowitz-May2006.pdf>

\section{Autorka}

Alena Macková je doktorandkou na Katedře politologie Fakulty sociálních studií Masarykovy univerzity a studentkou sociologie na téže fakultě.

Kontakt: aja.mackova@gmail.com 